\title{
Adenovirus-mediated interleukin- 12 gene transfer combined with cytosine deaminase followed by 5 -fluorocytosine treatment exerts potent antitumor activity in Renca tumor-bearing mice
}

\author{
Kyung-Sun Hwang1, Won-Kyung Cho' ${ }^{1}$, Jinsang Yoo ${ }^{1}$, Hwan-Jung Yun ${ }^{2}$, \\ Samyong $\mathrm{Kim}^{2}$ and Dong-Soo Im*1
}

\begin{abstract}
Address: ${ }^{1}$ Laboratory of Gene Therapy and Virology, Korea Research Institute of Bioscience and Biotechnology, Yusong, Daejeon, Republic of Korea and 2Department of Internal Medicine, College of Medicine, Chungnam National University, Daejeon, Republic of Korea

Email: Kyung-Sun Hwang - hwangksun@hanmail.net; Won-Kyung Cho - dna-g@hanmail.net; Jinsang Yoo - idolujis@kribb.re.kr; HwanJung Yun - hjyun@cnuh.co.kr; Samyong Kim - frkim@cnu.ac.kr; Dong-Soo Im* - imdongsu@kribb.re.kr

* Corresponding author
\end{abstract}

Published: 24 May 2005

BMC Cancer 2005, 5:5। doi:|0.|186/|47|-2407-5-5।
Received: 12 November 2004

Accepted: 24 May 2005

This article is available from: http://www.biomedcentral.com/I47|-2407/5/5 I

(C) 2005 Hwang et al; licensee BioMed Central Ltd.

This is an Open Access article distributed under the terms of the Creative Commons Attribution License (http://creativecommons.org/licenses/by/2.0), which permits unrestricted use, distribution, and reproduction in any medium, provided the original work is properly cited.

\begin{abstract}
Background: Therapeutic gene transfer affords a clinically feasible and safe approach to cancer treatment but a more effective modality is needed to improve clinical outcomes. Combined transfer of therapeutic genes with different modes of actions may be a means to this end. Interleukin-I2 (IL-I2), a heterodimeric immunoregulatory cytokine composed of covalently linked p35 and p40 subunits, has antitumor activity in animal models. The enzyme/prodrug strategy using cytosine deaminase $(C D)$ and 5 -fluorocytosine $(5-F C)$ has been used for cancer gene therapy. We have evaluated the antitumor effect of combining IL- 12 with CD gene transfer in mice bearing renal cell carcinoma (Renca) tumors.
\end{abstract}

Methods: Adenoviral vectors were constructed encoding one or both subunits of murine IL-12 (Ad.p35, Ad.p40 and Ad.IL-I2) or cytosine deaminase (Ad.CD). The functionality of the IL-I2 or $C D$ gene products expressed from these vectors was validated by splenic interferon (IFN)- $\gamma$ production or viability assays in cultured cells. Ad.p35 plus Ad.p40, or Ad.IL-I2, with or without Ad.CD, were administered (single-dose) intratumorally to Renca tumor-bearing mice. The animals injected with Ad.CD also received 5-FC intraperitoneally. The antitumor effects were then evaluated by measuring tumor regression, mean animal survival time, splenic natural killer (NK) cell activity and IFN- $\gamma$ production.

Results: The inhibition of tumor growth in mice treated with Ad.p35 plus Ad.p40 and Ad.CD, followed by injection of 5-FC, was significantly greater than that in mice treated with Ad.CD/5-FC, a mixture of Ad.p35 plus Ad.p40, or Ad.GFP (control). The combined gene transfer increased splenic NK cell activity and IFN- $\gamma$ production by splenocytes. Ad.CD/5-FC treatment significantly increased the antitumor effect of Ad.IL- 12 in terms of tumor growth inhibition and mean animal survival time.

Conclusion: The results suggest that adenovirus-mediated IL- 12 gene transfer combined with Ad.CD followed by 5 -FC treatment may be useful for treating cancers. 


\section{Background}

Gene therapy for treating cancers has been intensively investigated. Therapeutic gene transfer using viral or nonviral vectors has been shown to be clinically feasible and safe. However, the therapeutic outcome appears not to be high as expected, presumably because the in vivo gene delivery efficiency is low. In this sense, a more effective modality is needed to improve the therapeutic benefit. Combined transfer of genes with different mechanisms of action may potentate the therapeutic outcome. Indeed, combination cancer gene therapy using cytokine and suicide genes has been shown to be more effective than single gene transfer in animal models [1-9].

Interleukin (IL)-12 is a heterodimeric cytokine composed of 35- and 40-kDa subunits, which are covalently linked by a disulfide bond [10,11]. IL-12 stimulates interferon- $\gamma$ (IFN- $\gamma$ ) production by natural killer (NK) cells, enhances the cytolytic activities of NK cells and cytotoxic T lymphocytes (CTLs), stimulates the differentiation of Th1 cells and inhibits angiogenesis [12-14]. These biological activities have provided a rationale for the use of IL-12 in cancer immunotherapy. In fact, recombinant IL-12 (rIL12) exhibits significant antitumor activity in various animal models [12-14]. Subsequent phase I and II studies on various cancer types using intravenous or subcutaneous administration of human rIL-12 [15,16] showed some beneficial responses, but there were also adverse effects, which interrupted the clinical trials $[17,18]$. Recently, it has been reported that intratumoral administration of rIL12 shows dose-limiting toxicity and results in measurable locoregional immunological responses in head and neck squamous cell carcinoma patients [19].

Since intratumoral IL-12 gene transfer could minimize the adverse effects of systemic rIL-12 administration [17], the effectiveness against tumors of cell vaccines expressing IL12 , or viral or nonviral vectors encoding IL-12, has been evaluated in various animal models [18,20-23]. The results indicate that, compared to IL-2, IL-4, interferons, and granulocyte-macrophage colony-stimulating factor, IL-12 is one of the most effective immunomodulators for cancer treatment $[13,18,20,21,23]$. Pilot clinical trials have been conducted in patients with advanced primary and metastatic liver cancer on the basis of these results [24]. Intratumorally administered adenoviral vectors expressing IL-12 had low efficacy but no cumulative toxicity [24].

Suicide gene therapy deploys genes such as cytosine deaminase (CD), herpes simplex or varicella zoster virus thymidine kinase (TK), or nitroreductase, all of which convert nontoxic prodrugs into cytotoxic agents [25-27]. Systemically administered prodrugs are converted to the active agents only in cells expressing these suicide genes, so the therapeutic effect is maximized while systemic toxicity is reduced. CD, which normally catalyzes the deamination of cytosine to uracil during RNA biosynthesis, is found in many bacteria and fungi but not in mammalian cells [28-30]. It also deaminates 5-fluorocytosine (5-FC) to 5-fluorouracil (5-FU), which is highly toxic to cells. 5FU has been used clinically since the late 1950s to treat colorectal cancer [31]. A cellular metabolite of 5-FU, 5fluorouridine triphosphate, is incorporated into RNA in place of UTP and consequently the multiple functions of RNA are impaired. Another metabolite of 5-FU, 5-fluorodeoxyuridine monophosphate, blocks thymidylate synthase activity and thus inhibits DNA synthesis.

No currently available gene delivery system can deliver therapeutic genes including suicide genes to all the target cells in vivo. However, tumor cells expressing a suicide gene can kill neighboring tumor cells that do not express this gene by the by-stander effect, which could partly overcome the gene delivery problem [32-35]. A number of suicide gene therapies have been shown to be effective against various cancer cell lines in culture and in animal models. Subsequent phase I, II or III studies using CD or TK genes were performed in colorectal cancer patients with liver metastases and in brain tumor patients [36-47]. The antitumor activities appeared less than expected [46], but the results showed that suicide gene therapy is safe to apply in the oncology clinic [36-47].

A combination of IL-2 and TK genes exerted a more potent therapeutic outcome in a metastatic carcinoma model, and induced antitumor immunity [1]. Since then, combination gene therapies using various cytokine and suicide genes have been intensively investigated [2-9]. In the present study, we investigated the effectiveness of combined transfer of IL-12 and CD genes against renal cell carcinoma (Renca)-tumors in mice.

\section{Methods \\ Cells and mice}

HeLa, 293, Renca (a cell line spontaneously derived from $\mathrm{BALB} / \mathrm{c}$ renal cell adenocarcinoma), and NK cell-sensitive YAC-1 cells were cultured in DMEM or RPMI-1640 medium (Gibco-BRL) supplemented with 10\% fetal bovine serum (FBS) and penicillin/streptomycin. Cultures were maintained in a $5 \% \mathrm{CO}_{2}$ atmosphere at $37^{\circ} \mathrm{C}$.

Male or female wild-type BALB/c mice, 7-8 weeks of age, were purchased from the animal breeding laboratory at the Korea Research Institute of Bioscience and Biotechnology. They were kept (five mice per cage) in isolation under specific pathogen-free conditions, exposed to 12-h light/ 12-h dark cycles, and provided with standard feed and water ad libitum. 


\section{Construction of replication-defective adenoviral vectors} cDNAs for Esherichia coli cytosine deaminase, p35 and/or p40 murine IL-12 subunits [48] or green fluorescent protein (GFP) were inserted by a standard cloning procedure into pX.dCMV.pA, an adeno-transfer plasmid harboring the immediate early gene promoter from human cytomegalovirus [49-51]. The shuttle plasmids were cotransfected into 293 cells together with pJM17, which harbors the genomic DNA of adenovirus 5 (Microbix, Canada), by a standard calcium phosphate method. Primary plaques were isolated and screened by PCR to ensure the presence of the inserts. Positive clones were plaque-purified twice and a single plaque was chosen for further amplification in 293 cells. Recombinant adenoviruses were purified by cesium chloride gradient centrifugation as previously described [49-51], dialyzed to remove the cesium chloride and frozen at $-70^{\circ} \mathrm{C}$.The viral titer was determined by a 293 plaque assay and expressed as plaque-forming units (pfu).

\section{Cell viability assay}

HeLa cells were plated on $60-\mathrm{mm}$ dishes at $5 \times 10^{5}$ cells/ plate and mock-transduced, or transduced with Ad.CD, for $2 \mathrm{~h}$ at a multiplicity of infection (MOI) of 50 in serumfree DMEM. Cultures were continued for a further $12 \mathrm{~h}$. Transduced and non-transduced cells were then mixed in different ratios and incubated in 24-well dishes for $24 \mathrm{~h}$. The culture media were replaced with fresh media containing various concentrations of 5-FC, and incubation was continued for 4 days. Cell viability was assessed by the trypan-blue exclusion assay.

\section{Western blotting}

HeLa cells were plated on $60-\mathrm{mm}$ dishes at $5 \times 10^{5}$ cells/ dish and transduced with recombinant adenoviruses in serum-free DMEM for $2 \mathrm{~h}$. The culture media from mockor virus-transduced cells were retained for measurement of released IL-12 at $48 \mathrm{~h}$ postinfection, and the cells were harvested in a lysis buffer $(10 \mathrm{mM}$ Tris- $\mathrm{HCl}, \mathrm{pH} 7.5,10$ $\mathrm{mM} \mathrm{NaCl}, 1.5 \mathrm{mM} \mathrm{MgCl}_{2}, 10 \mathrm{mM} \beta$-mercaptoethanol). Cell extracts were prepared by three cycles of freezing ($70^{\circ} \mathrm{C}$ ) and thawing and precleared by centrifugation. Fifty micrograms of precleared cell lysates were subjected to SDS-10\% polyacrylamide gel electrophoresis (PAGE). The separated proteins were transferred to PVDF membranes, which were blocked with $3 \%$ bovine serum albumin (BSA) in phosphate-buffered saline (PBS) and incubated with rat anti-mouse IL-12 antibody (PharMingen), then with horseradish peroxidase-conjugated rabbit anti-rat $\lg$ antibody (Sigma). Proteins were detected according to Amersham's ECL protocol. The culture supernatants were incubated with anti-IL-12 antibody. A suspension of protein G-Sepharose beads $(100 \mu \mathrm{l})$ was added and the incubation mixtures were further incubated at $4^{\circ} \mathrm{C}$ for $12 \mathrm{~h}$. The immunoprecipitates were washed three times with 40
$\mathrm{mM} \quad \mathrm{N}$-2-hydroxyethylpiperazine-N'-2-ethanesulfonic acid, pH 7.4, $100 \mathrm{mM} \mathrm{KCl,} \mathrm{0.1 \%} \mathrm{NP-40,} 0.1 \mathrm{mM}$ DTT, and once with PBS, then immunoblotted with the rat antimouse IL-12 antibody described above.

\section{Animal model and treatment}

Tumors were generated on the flanks of BALB/c mice by subcutaneous (s.c.) injection of $1.5 \times 10^{5}$ of Renca cells in $0.1 \mathrm{ml}$ of PBS. After visible tumors had developed for 7-9 days after inoculation, the mice were injected once intratumorally with recombinant adenoviruses at $1 \times 10^{9} \mathrm{pfu}$ in $10 \mathrm{mM}$ Tris-HCl, pH 7.4, $1 \mathrm{mM} \mathrm{MgCl}_{2}, 10 \%$ glycerol. Animals undergoing 5-fluorocytosine therapy received intraperitoneal administration of 5-FC (400 mg/kg) daily for 10 days. Tumors were measured prior to virus injection and subsequently at intervals of 3 days. Linear calipers were used to measure the longest diameter (a), width (b), and depth (c). The tumor size was calculated by the formula: $(\mathrm{a} \times \mathrm{b} \times \mathrm{c} / 2)$.

\section{ELISA for IFN- $\gamma$}

ELISAs were performed using essentially the reagents and procedures described in the Endogen (USA) product literature. Flat-bottomed 96-well microtiter plates (Nunc Maxisorp) were coated with rat anti-IFN- $\gamma$ antibodies $(1 \mu \mathrm{g} /$ $\mathrm{ml}$ ) at $4^{\circ} \mathrm{C}$ overnight and blocked with $4 \%$ BSA in PBS for $2 \mathrm{~h}$ at $37^{\circ} \mathrm{C}$. Renca cells were treated with mitomycin $\mathrm{C}$ at $50 \mu \mathrm{g} / \mathrm{ml}$ for $20 \mathrm{~min}$ at $37^{\circ} \mathrm{C}$. Splenocytes $\left(2 \times 10^{6}\right.$ cells $/$ $\mathrm{ml}$ ) obtained from the tumor-bearing mice 21 days after virus treatment were stimulated with the inactivated Renca cells in U-bottomed 96-well plates at an effector-tostimulator ratio of 10:1. Supernatants $(50 \mu \mathrm{l})$ from $24 \mathrm{~h}$ and $48 \mathrm{~h}$ cultures were added to the ELISA plate wells and incubated for $1 \mathrm{~h}$. After several washing steps, rat antimouse IFN- $\gamma$ antibody conjugated with biotin was added. Color was developed using avidin-conjugated horseradish peroxidase and OPD substrate (Sigma). The reaction was terminated by the addition of $2 \mathrm{~N} \mathrm{H}_{2} \mathrm{SO}_{4}$. The absorbance was measured at $490 \mathrm{~nm}$ with an ELISA plate reader. The amounts of IFN- $\gamma$ were quantified by interpolation of a standard curve generated using known amounts of standard mouse rIFN- $\gamma$ (Endogen). The biological activity of the IL-12 produced from the recombinant adenoviruses was assessed on the basis of its ability to induce IFN- $\gamma$ secretion from murine splenocytes. Murine splenocytes $(1.5 \times$ $10^{6}$ cells/well) were washed with cold medium and incubated with the culture supernatants. IFN- $\gamma$ in the incubation media was then determined by an ELISA, as described above.

\section{Cytotoxicity assay of $\mathrm{NK}$ cells}

The cytolytic activity of NK cells was determined by a standard 4-h ${ }^{51} \mathrm{Cr}$-release assay. The spleens from dead mice obtained 21 days after tumor inoculation were removed aseptically and single-cell suspensions, prepared 
by passing the spleens through a metal mesh, were suspended in $5 \mathrm{ml}$ of $0.83 \%$ ammonium chloride to lyse the red blood cells. The splenocytes were then used as effector cells to assay NK cell activity. YAC- 1 cells $\left(2 \times 10^{6}\right)$ in 0.5 $\mathrm{ml}$ of RPMI-1640 with $20 \%$ FBS were labeled with $50 \mu \mathrm{Ci}$ of $\mathrm{Na}^{51} \mathrm{CrO}_{4}$ (Amersham) for $90 \mathrm{~min}$. The labeled cells were washed three times with serum-free DMEM and mixed $\left(1 \times 10^{4}\right.$ per well $)$ with the effector cells in a U-bottomed 96-well plate for $4 \mathrm{~h}$ at $37^{\circ} \mathrm{C}$ at three different effector-to-target ratios (100:1, 33:1, and 11:1), each in triplicate. The mixtures of target and effector cells were incubated for $4 \mathrm{~h}$ at $37^{\circ} \mathrm{C}$. The percentage of specific ${ }^{51} \mathrm{Cr}$ release was calculated as [(cpm experimental release - cpm spontaneous release/cpm maximum release - cpm spontaneous release) $] \times 100$. The maximum ${ }^{51} \mathrm{Cr}$ release was determined from the supernatant when labeled cells were lysed by adding $0.1 \mathrm{ml}$ of $3 \%$ SDS. Spontaneous release was determined from the supernatants after labeled cells were incubated in $0.1 \mathrm{ml}$ of medium without effector cells. The standard deviations for each triplicate sample and for spontaneous release were less than $10 \%$ and $20 \%$, respectively.

\section{Statistics}

Statistical analysis was carried out using the Student's $t$ test (unipolar, paired) and the chi-square test (two-tailed). The values were considered statistically significant when the $P$ value was less than 0.05 .

\section{Results and discussion}

Recombinant adenoviruses encoding the p35 andlor p40 subunits of murine IL- $\mathbf{2}$ express bioactive IL- $\mathbf{2}$

We constructed replication-defective adenoviruses containing the p35 and/or p40 subunits of murine IL-12 under the transcriptional control of the immediate early gene promoter of human cytomegalovirus (Figure 1). Ad.IL-12 contains murine cDNAs of both IL-12 subunits, which are linked by an internal ribosome entry site sequence from encephalomyocarditis virus. To test whether Ad.p40 and Ad.IL-12 express the p40 subunit and the p35-p40 heterodimer respectively, we transduced HeLa cells with the two constructs at the indicated MOI. Replication-defective adenovirus encoding GFP (Ad.GFP) was used as a control. Lysates of cells transduced with Ad.p40 or Ad.GFP were resolved by SDS-PAGE followed by immunoblotting with anti-IL-12 antibody, which reacts specifically with the p40 subunit of mouse IL-12 and with free p40 (Figure 2A, left panel). Ad.p40 was found to express $\mathrm{p} 40$. The culture media from cells transduced with Ad.IL-12 or Ad.GFP were immunoprecipitated with anti-IL-12 antibody. The immuno-complexes were resolved by SDS-PAGE under nonreducing conditions and immunoblotted with anti-IL-12 antibody. The two protein bands detected might be a p40 homodimer (p80) and a p35-p40 heterodimer (p70) (Figure 2A, right panel,

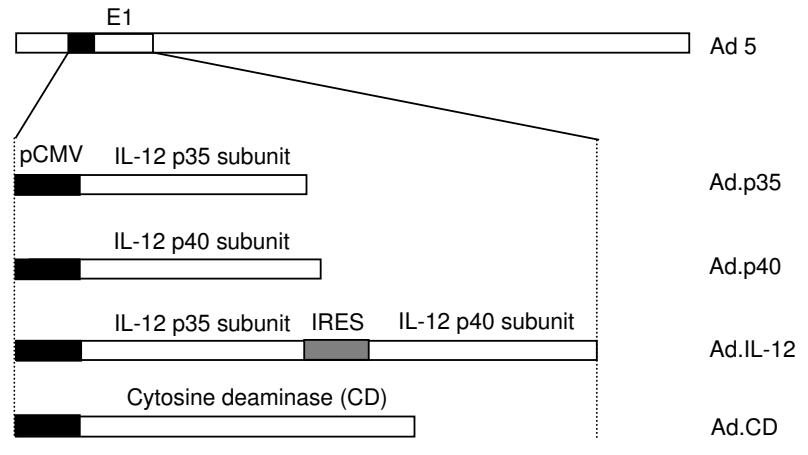

\section{Figure I}

Schematic illustration of replication-defective adenoviral vectors constructed in this study. The EI region of adenovirus type 5 (Ad 5) was replaced by the indicated genes under the transcriptional control of the immediate early gene promoter from human cytomegalovirus (PCMV). IRES; internal ribosomal entry sequence.

indicated by arrows). Under nonreducing conditions, Ad.IL-12 produced a doublet of 79/75 kDa that was sensitive to a reducing agent [52]. Ad.p40 produces a band migrating with an apparent molecular mass of approximately $90 \mathrm{kDa}$, which on a reducing gel reveals a band consistent with the p40 monomer [53]. Thus, our result appeared to be consistent with previous findings. We could not assess p35 expression because no antibody specific for this subunit was available.

We next examined whether cells transduced with adenoviruses encoding the p35 and/or p40 subunits release bioactive IL-12. HeLa cells were mock-transduced, or transduced with a 1:1 (pfu ratio) mixture of Ad.p35 and Ad.p40, Ad.IL-12, or Ad.GFP at the indicated MOI, and the culture supernatants were collected after $24 \mathrm{~h}$ incubation. Splenocytes from naïve mice were incubated with equivalent volumes of the culture supernatants, and the IFN- $\gamma$ contents of the medium were measured using ELISA (Figure 2B and 2C). The culture supernatants from cells transduced with a mixture of Ad.p35 and Ad.p40 or Ad.IL12 exhibited much higher IFN- $\gamma$ inducing-activity than the controls. These results suggest that cells transduced with Ad.p35 plus Ad.p40 or Ad.IL-12 release bioactive IL-12.

\section{Recombinant adenovirus encoding cytosine deaminase (Ad.CD) expresses catalytically active cytosine deaminase} We constructed a replication-defective adenovirus encoding cytosine deaminase (Figure 1). To examine whether the Ad.CD virus expresses cytosine deaminase capable of converting 5-FC to cytotoxic 5-FU, we transduced HeLa cells with Ad.CD at an MOI of 50. Naïve HeLa or HeLa/ 

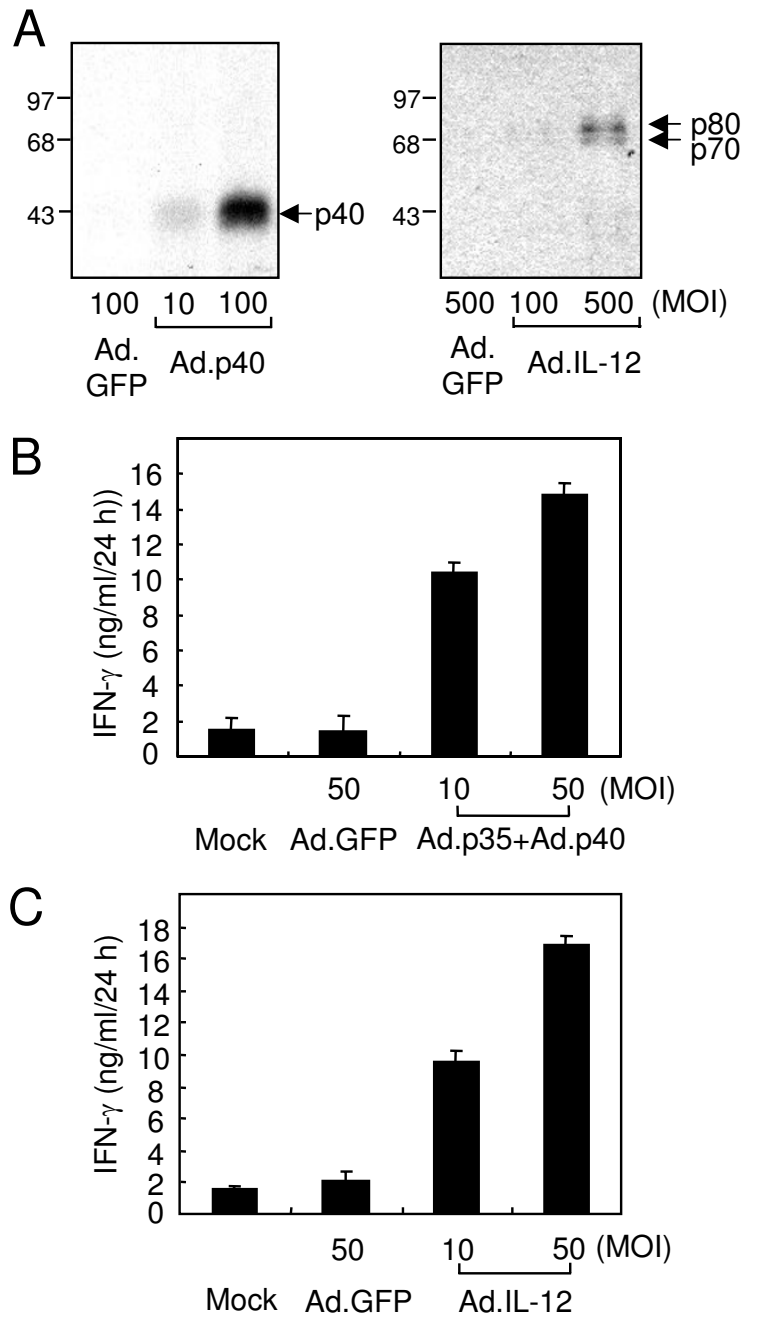

Figure 2

The recombinant adenoviruses encoding murine p35 and/or p40 subunits express biologically active IL- I2. (A) HeLa cells were transduced with Ad.GFP, Ad.p40, or Ad.IL- 12 at the indicated MOls. Cells or culture media were harvested $48 \mathrm{~h}$ after transduction. Cleared lysates of cells transduced with Ad.GFP or Ad.p40 were immunoblotted with anti-IL- 12 antibody (left panel). The culture media from HeLa cells transduced with Ad.IL-I 2 or Ad.GFP were immunoprecipitated with anti-IL- 12 antibody. The immunoprecipitates were dissolved in SDS sample buffer without reducing agent and subjected to SDS-PAGE, followed by immunoblotting with antiIL-I 2 antibody (right panel). Molecular size markers in kilodaltons are shown at the left. The positions of p40, p35-p40 heterodimer (p70) and $p 40$ homodimer $(p 80)$ are indicated by arrows. ( $\mathrm{B}$ and $\mathrm{C}$ ) HeLa cells were mock-transduced or transduced with either a I:I (pfu ratio) mixture of Ad.p35 and Ad.p40, or Ad.IL-12, or Ad.GFP, at the indicated MOI. Splenocytes from naïve mice were incubated with the culture supernatants for $24 \mathrm{~h}$. ELISA was performed to determine the IFN- $\gamma$ levels after incubation. Data are means \pm SD of two independent experiments, each performed in duplicate.

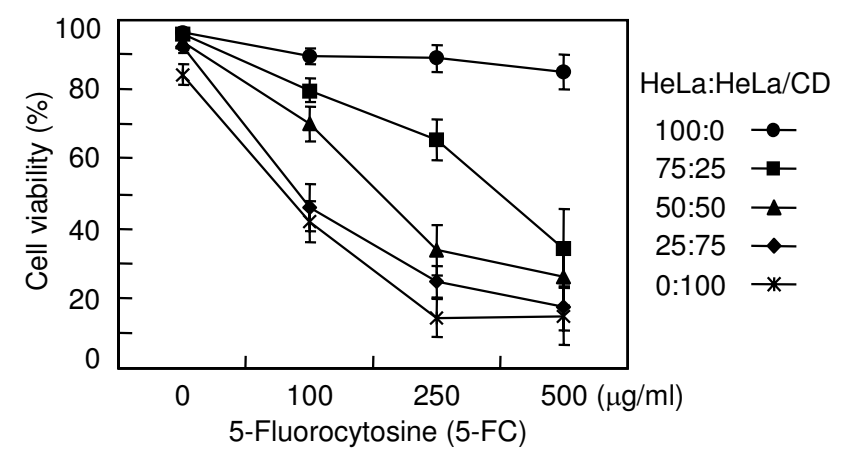

Figure 3

Ad.CD virus expresses functional cytosine deaminase. HeLa cells were transduced with Ad.CD at an MOI of 50 and incubated for $12 \mathrm{~h}$. These cells $(\mathrm{HeLa} / \mathrm{CD})$ were then mixed with naïve HeLa cells at the indicated ratios. The HeLa/CD, HeLa, or mixed cells were incubated on 24-well dishes for $24 \mathrm{~h}$, then treated with 5-FC at the indicated concentrations for 4 days. Cell viability was assessed by the trypan-blue exclusion assay. Data are means \pm SD of two independent experiments, each performed in duplicate.

CD cells, or mixtures of the two at the indicated ratios (Figure 3), were incubated in culture media without or with the indicated concentrations of 5-FC for 4 days, and cell viability was assessed by the trypan-blue exclusion assay (Figure 3). In the presence of 5-FC, the viability of the HeLa/CD cells decreased markedly but the naïve HeLa cells were unaffected, suggesting that cytosine deaminase was expressed in the virus-transduced cells and metabolized 5-FC to 5-FU. The viability of the mixtures of naïve and HeLa/CD cells appeared to decrease more than the proportion of naïve cells in the mixtures, particularly with $500 \mu \mathrm{g} / \mathrm{ml} 5$-FC. Thus, the Ad.CD virus appeared to exert a bystander effect, though not a drastic one. The results suggest that Ad.CD expresses catalytically active cytosine deaminase.

\section{Transfer of the IL-I 2 and cytosine deaminase genes in combination, followed by 5-FC treatment, exerts potent antitumor activity in Renca-tumor bearing mice}

Renca-tumor bearing mice were established as described in the Methods section, randomly divided into 4 groups, and injected once intratumorally with Ad.GFP, Ad.CD/5FC, Ad.p35 plus Ad.p40, or Ad.p35 plus Ad.p40 plus Ad.CD. Mice receiving Ad.CD were treated with 5-FC. Tumor growth was measured at the indicated times (Figure 4A). Mouse survival until day 42 was recorded (Figure $4 \mathrm{~B})$. The treatment outcomes are summarized in Table 1. Inhibition of tumor growth was most marked in mice treated with Ad.p35 plus Ad.p40 plus Ad.CD/5-FC $(p<$ 
A

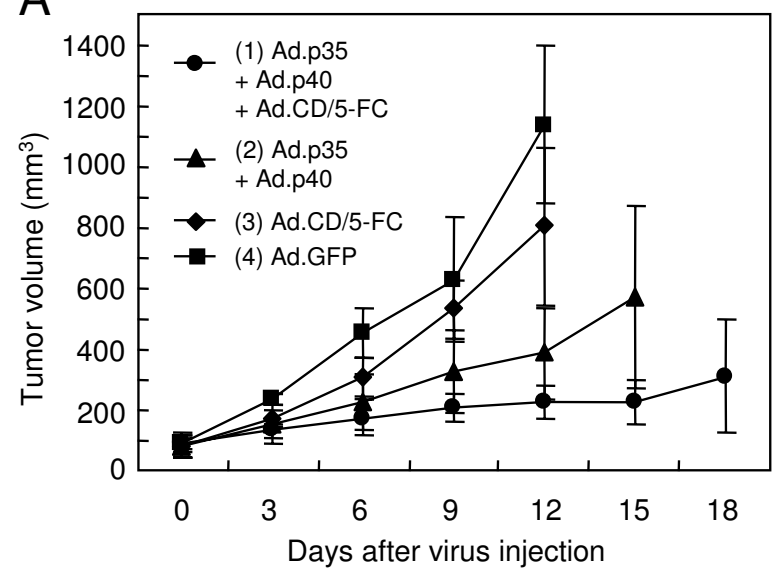

B

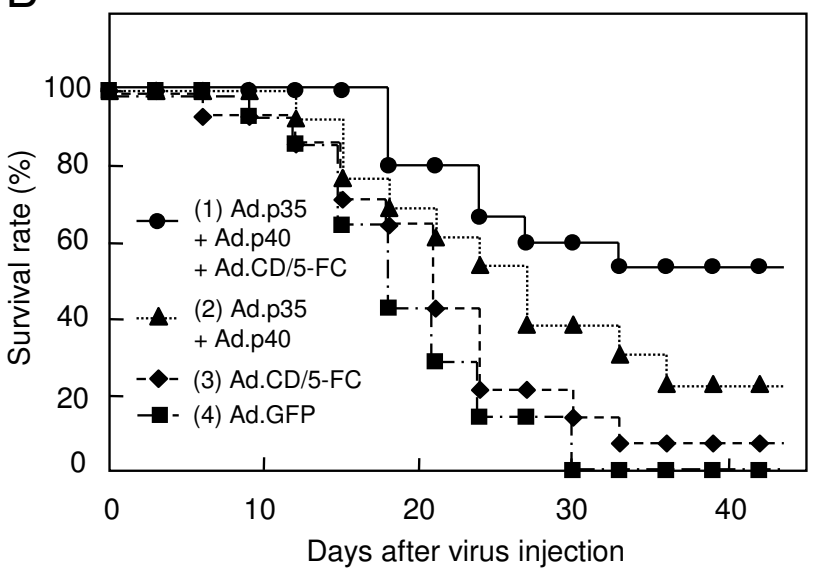

Figure 4

The antitumor activity effected by IL- 12 gene transfer increases in vivo when combined with cytosine deaminase/5-FC. (A) Renca tumors were established in BALB/c mice by s.c. inoculation of $1.5 \times 10^{5}$ cells. When the tumors reached $5-6 \mathrm{~mm}$ diameter, the animals were randomly divided into four treatment groups $(n=15$ per group) and injected once intratumorally with (I) Ad.p35 $\left(2.5 \times 10^{8} \mathrm{pfu}\right)$ plus Ad.p40 (2.5 $\left.\times 10^{8} \mathrm{pfu}\right)$ plus Ad.CD $\left(5 \times 10^{8} \mathrm{pfu}\right)$, or $(2)$ Ad.p35 $\left(5 \times 10^{8} \mathrm{pfu}\right)$ and Ad.p40 $\left(5 \times 10^{8} \mathrm{pfu}\right)$, or (3) Ad.CD $\left(I \times 10^{9} \mathrm{pfu}\right)$, or (4) Ad.GFP $\left(\mathrm{I} \times 10^{9} \mathrm{pfu}\right)$. Mice treated with Ad.CD were given 5-FC $(400 \mathrm{mg} / \mathrm{kg})$ intraperitoneally daily for 10 days. Graphic representations of mean tumor growth rates are shown. Bars indicate SD. (B) Mouse survival until day 42 was recorded. Mice were sacrificed and considered as death when tumor size exceeded $1.5 \mathrm{~cm}$ in long and short axes. The mean survival times $( \pm$ SD) were $33.2 \pm 10.4$ days for (I) group, $27.2 \pm 10.9$ days for (2) group, $21.9 \pm 9.1$ days for (3) group, and $19.7 \pm 7.1$ days for (4) group. The difference between $(I)$ and $(2)$ groups was statistically significant $(p<0.0018)$ by Student's $t$ test. The treatment outcome is summarized in Table I. One animal in each of the groups treated with Ad.CD and Ad.GFP succumbed to toxicity, and two mice in the group treated with Ad.p35 plus Ad.p40 were excluded owing to peritoneal metastasis.

Table I: Tumor regression following intratumoral injection of Ad.p35 plus Ad.p40, or Ad.CD/5-FC alone, or a combination of both

\begin{tabular}{|c|c|c|c|c|c|}
\hline \multirow[t]{2}{*}{ Treatment } & \multicolumn{5}{|c|}{ Response (\%) } \\
\hline & $N$ & Complete & Partial & $\begin{array}{c}\text { Death or peritoneal } \\
\text { metastasis }\end{array}$ & None \\
\hline Ad.p35 + Ad.p40 + Ad.CD/5-FC & 15 & $4(27)$ & $4(27)$ & $0(0)$ & $7(46)$ \\
\hline Ad.p35 + Ad.p40 & 15 & I (7) & $2(14)$ & $\ddagger 2(13)$ & $10(66)$ \\
\hline Ad.CD/5-FC & 15 & I (7) & $0(0)$ & $+1(7)$ & $13(86)$ \\
\hline Ad.GFP & 15 & $0(0)$ & $0(0)$ & †I (7) & $14(93)$ \\
\hline
\end{tabular}

$N=$ number of Renca tumor-bearing mice injected once intratumorally with adenoviral vectors at the doses indicated in Figure 4 legend.

"Complete" refers to animals undergoing total and permanent regression of the injected tumor.

"Partial" refers to animals undergoing partial tumor regression followed by regrowth, or a significant delay in growth

"Death or peritoneal metastasis" refers to animals that died or had peritoneal metastasis during the period of investigation.

None refers to animals whose tumors have continued to grow at a rate comparable to controls.

†Death probably by toxicity.

fExcluded due to peritoneal metastasis during the experiment.

0.001 for Ad.p35 plus Ad.p40 plus Ad.CD/5-FC vs Ad.GFP and $p<0.0053$ for Ad.p35 plus Ad.p40 plus Ad.CD/5-FC vs Ad.CD/5-FC). The mean survival times were for $33.2 \pm$ 10.4 days for Ad.p35 plus Ad.p40 plus Ad.CD/5-FC group and $27.2 \pm 10.9$ days for Ad.p35 plus Ad.p40 group; the difference is statistically significant $(p<0.0018)$. Among the 15 mice treated with Ad.p35 plus Ad.p40 plus Ad.CD/ 5 -FC, four became tumor-free and four exhibited partial 

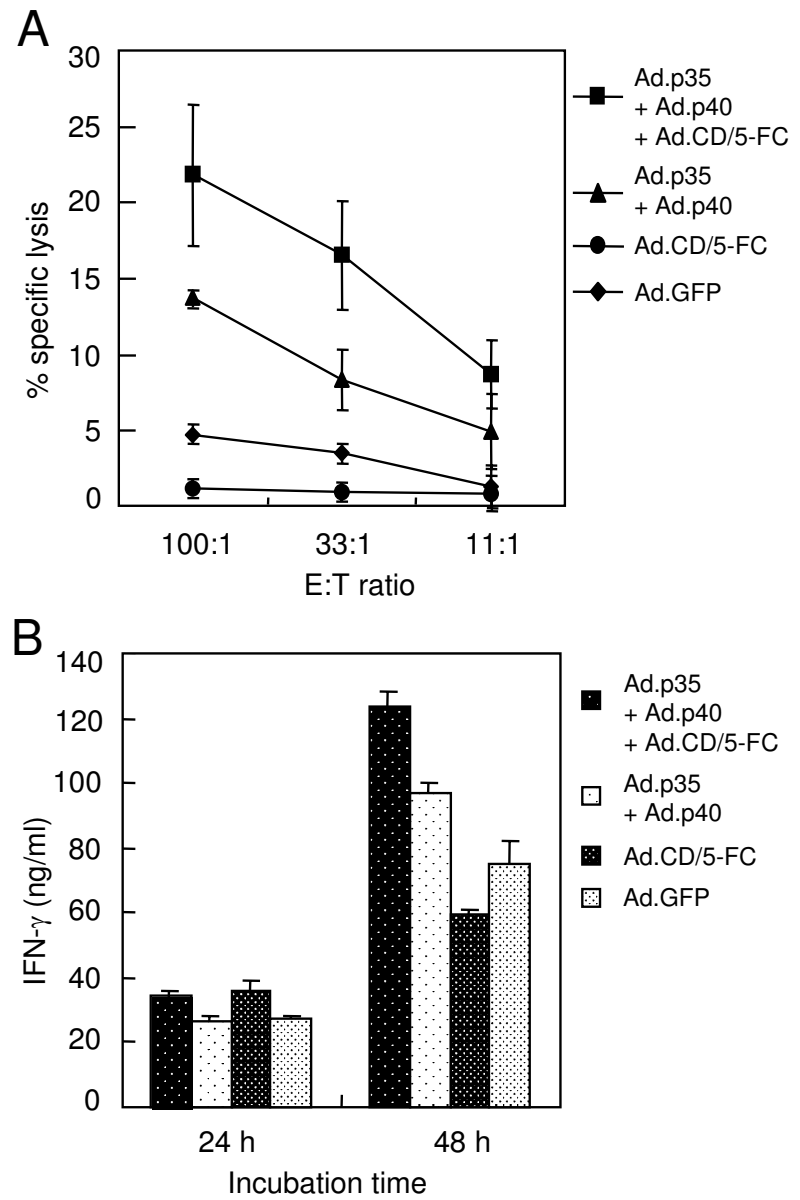

\section{Figure 5}

IL-I 2 gene transfer combined with Ad.CD/5-FC increases splenic NK cell activity and IFN- $\gamma$ production. (A) Cytotoxicity of NK cells in Renca tumor-bearing mice treated with various adenoviral vectors (see Figure 4 legend). Mice in which tumor growth was completely or partially inhibited were chosen from the treatment groups on day $2 \mathrm{I}$ after tumor cell inoculation. Splenocytes were isolated from the treated mice ( $n=3$ per group) and used as effector cells. A standard 4-h ${ }^{5 I} \mathrm{Cr}$ release assay was performed using YAC-I cells labeled with ${ }^{51} \mathrm{Cr}$ as target cells. The percentage specific lysis was determined. Data are means \pm SD. (B) Mouse splenocytes ( $n$ $=3$ per group) were isolated from the treatment groups on day $2 \mathrm{I}$ as described above, and incubated with Renca cells inactivated by pretreatment with $50 \mu \mathrm{g} / \mathrm{ml}$ mitomycin $C$ for $20 \mathrm{~min}$ at $37^{\circ} \mathrm{C}$. Culture supernatants were obtained from the incubated cells at the indicated times. Amounts of IFN- $\gamma$ in the supernatants were measured using ELISA. Bars represent mean \pm SD.

responses (Table 1). Among the 15 mice treated with Ad.p35 plus Ad.p40, one became tumor-free and two showed partial responses $(p<0.0464$ for comparison of the two treatments). Ad.p35 plus Ad.p40 treatment appeared to be more effective than Ad.CD/5-FC, which had a modest antitumor effect compared to the control (Ad.GFP).

\section{IL- 2 and cytosine deaminase genes in combination, followed by 5-FC treatment, enhance the cytolytic activity of NK cells and increase IFN- $\gamma$ production}

We examined whether the increased antitumor activity of Ad.p35 plus Ad.p40 plus Ad.CD/5-FC (Figure 4) was associated with the induction of tumor-specific CTLs, activation of NK cells, and induction of Th1 cytokines such as IL-2 and IFN- $\gamma$. Effector cells were prepared from the splenocytes of tumor-bearing mice treated with the recombinant adenoviruses. Renca cells labeled with ${ }^{51} \mathrm{Cr}$ were used as target cells. A standard 4-h ${ }^{51}$ chromium release assay was carried out. However, we did not detect specific lysis of the labeled Renca cells (data not shown). We performed an NK cell assay using the splenocytes as effector cells and YAC-1 cells labeled with ${ }^{51} \mathrm{Cr}$ as target cells (Figure 5A). The effector cells from mice treated with Ad.p35 plus Ad.p40 plus Ad.CD/5-FC lysed the target cells about 10- and 5-fold more effectively than Ad.CD/5-FC and Ad.GFP, respectively, at a 100:1 effector-to-target cell ratio. Although Ad.p35 plus Ad.p40 treatment also increased NK cell activity compared to Ad.CD/5-FC or Ad.GFP, the cytolytic activity of splenic NK cells from mice treated with this mixture was lower than that from mice treated with Ad.p35 plus Ad.p40 plus Ad.CD/5-FC. The effector cells used in the NK cell assay were mainly splenocytes from mice in which the tumors were completely regressed or small. This may account for the increased NK cell activity in the Ad.p35 plus Ad.p40 plus Ad.CD/5-FC treatment group compared to the Ad.p35 plus Ad.p40 treatment group.

We next examined whether the virus treatments induced Th1 cytokines, which may represent innate and/or adaptive immune responses. Splenocytes from tumor-bearing mice treated with the viruses were incubated with inactivated Renca cells. The IL- 2 and IFN- $\gamma$ contents of the culture supernatants were measured by ELISA 24 and $48 \mathrm{~h}$ after incubation, respectively. We detected no IL-2 induction in splenocytes from any of the treatment groups (data not shown). However, IFN- $\gamma$ production was about twice as great in splenocytes from mice treated with Ad.p35 plus Ad.p40 plus Ad.CD/5-FC as in those treated with Ad.CD/5-FC or Ad.GFP (Figure 5B, $p<0.0179$ and $<$ 0.0394 for Ad.p35 + Ad.p40 + Ad.CD/5-FC vs Ad.GFP and Ad.CD/5-FC, respectively). Ad.p35 plus Ad.p40 treatment also increased IFN- $\gamma$, but its effectiveness was significantly less than that of Ad.p35 plus Ad.p40 plus Ad.CD/5-FC ( $p$ $<0.0076)$. The results suggest that Ad.p35 plus Ad.p40 treatment, but not Ad.CD/5-FC, may enhance NK cell 


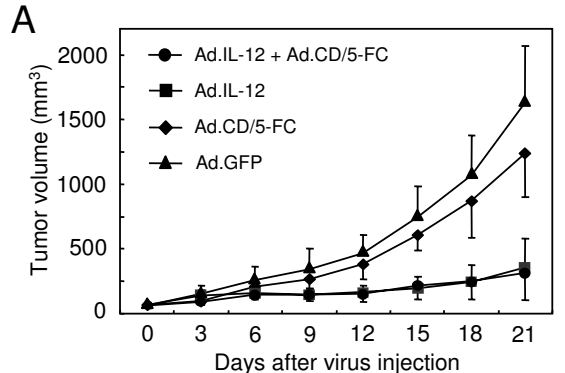

$\mathrm{B}$
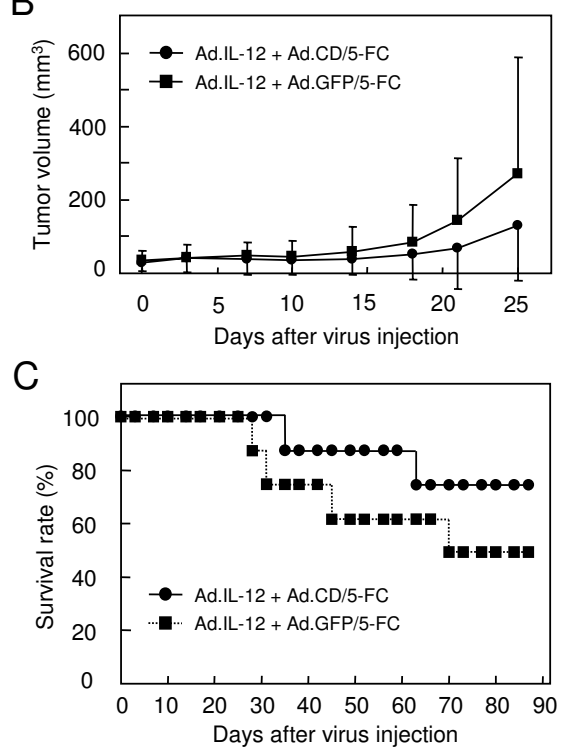

\section{Figure 6}

$\mathrm{CD}$ gene transfer followed by $5-\mathrm{FC}$ treatment increases the antitumor effectiveness of IL-I 2 gene transfer. (A) Mice with tumors were established by subcutaneous inoculation of I.5 $\times 10^{5}$ cells of Renca. The experimental animals in which tumors reached a diameter of about $5 \mathrm{~mm}$ were randomly divided into 4 treatment groups ( $n=7$ per group) and injected once intratumorally (day 0$)$ with Ad.IL-I2 $\left(5 \times 10^{8}\right.$ pfu) plus Ad.CD $\left(5 \times 10^{8} \mathrm{pfu}\right)$, or $1 \times 10^{9} \mathrm{pfu}$ of Ad.IL-12, or Ad.CD, or Ad.GFP. Mice treated with Ad.CD were given intraperitoneal $5-\mathrm{FC}(400 \mathrm{mg} / \mathrm{kg})$ daily for 10 days. Tumor growth was measured at intervals of three days until day 21 . Graphic representations of mean tumor growth rates are shown. (B) and (C) Renca tumor-bearing mice were divided into two groups ( $n=8$ per group), which received single intratumorally injections (day 0$)$ of Ad.IL- $12\left(5 \times 10^{8} \mathrm{pfu}\right)$ plus Ad.CD $\left(5 \times 10^{8} \mathrm{pfu}\right)$ or Ad.IL- $12\left(5 \times 10^{8} \mathrm{pfu}\right)$ plus Ad.GFP (5 $\left.\times 10^{8} \mathrm{pfu}\right)$. Mice in both groups were given intraperitoneal 5FC (400 mg/kg) daily for 10 days. Tumor growth was measured at the indicated times until day 25. Graphic representations of mean tumor growth rates are shown (B). Mouse survival until day 88 was recorded $(C)$. The mean survival times $( \pm S D)$ were $80.5 \pm 20.8$ days for the Ad.IL- I 2 plus Ad.CD/5-FC group and $67.3 \pm 28.3$ days for the Ad.IL- 12 plus Ad.GFP/5-FC group. The difference between these mean survival times was statistically significant $(p<0.0368)$ by Student's $t$ test. activity and stimulate IFN- $\gamma$ production. Thus, the enhancement of NK cell activity may be partially responsible for the inhibition of tumor growth by treatment with Ad.p35 plus Ad.p40 plus Ad.CD/5-FC or with Ad.p35 plus Ad.p40.

The rapid tumor cell killing effect induced by suicide gene products induces a strong antitumor immune response, such as induction of tumor-specific CTLs and increased NK cell activity [54-57]. However, we detected neither a tumor-specific T cell immune response nor an enhanced NK cell activity after Ad.CD/5-FC treatment alone. It is possible that the antitumor activity of the Ad.CD constructed here was so weak that the tumor cells were not killed rapidly (Figure 4). However, this is unlikely, because Ad.CD/5-FC treatment increased the antitumor activity of Ad.IL-12 (see Figure 6B and 6C). Alternatively, the bystander effect, which kills neighboring tumor cells not expressing suicide genes, may have exerted a negative effect on the generation of tumor-specific CTL and/or active NK cells. Immune cells or antigen-presenting cells located close to the tumor cells could have taken up, and been killed by, the toxic metabolites generated by the suicide gene products. This may explain why the NK cell activity in Ad.CD-treated mice was significantly lower than in Ad.GFP-treated mice (Figure 5A, $p<0.001$ ).

Transfer of the cytosine deaminase gene followed by 5 FC treatment increases the antitumor effectiveness of IL12 gene transfer in Renca-tumor bearing mice

Since a mixture of Ad.p35 and Ad.p40 was used in previous experiments (Figure 4), we examined whether Ad.IL12 , containing p 35 and $\mathrm{p} 40$ in a single adenoviral vector (Figure 1), was more effective against the tumors when combined with Ad.CD/5-FC. Renca-tumor bearing mice were divided randomly into four groups, treated intratumorally with (1) Ad.IL-12 plus Ad.CD/5-FC, (2) Ad.IL-12, (3) Ad.CD/5-FC, or (4) Ad.GFP (control). Tumor sizes were measured at the indicated times (Figure 6A). There was a significant inhibition of tumor growth in mice treated with Ad.IL-12 plus Ad.CD/5-FC compared to Ad.GFP $(p<0.0456)$. The effectiveness of Ad.IL-12 $(5 \times$ $\left.10^{8} \mathrm{pfu}\right)$ plus Ad.CD/5-FC $\left(5 \times 10^{8} \mathrm{pfu}\right)$ appeared to be similar to that of Ad.IL-12 $\left(1 \times 10^{9} \mathrm{pfu}\right)$ alone. This contrasts with the effectiveness of Ad.p35 plus Ad.p40 plus Ad.CD/5-FC as compared to Ad.p35 plus Ad.p40 (Figure 4). Presumably the in vivo gene delivery of the Ad.p35Ad.p40 mixture was not so efficient as that of Ad.IL-12.

We further examined whether CD gene transfer followed by 5 -FC treatment increased the antitumor effectiveness of IL-12 gene transfer. Sixteen Renca tumor-bearing mice were divided into 2 groups. Since a higher dose than $1 \times$ $10^{9} \mathrm{pfu}$ of adenoviral vector appeared to be toxic to the mice, the total dose given was $1 \times 10^{9} \mathrm{pfu}$. Mice in each 
group received Ad.IL-12 $\left(5 \times 10^{8} \mathrm{pfu}\right)$ with either Ad.CD $\left(5 \times 10^{8} \mathrm{pfu}\right)$ or Ad.GFP $\left(5 \times 10^{8} \mathrm{pfu}\right)$ as a control. Both groups were treated with 5 -FC for 10 days. Tumor sizes were measured at the indicated times (Figure 6B). Combined transfer of the IL-12 and CD/5-FC genes resulted in significant inhibition of tumor growth compared to IL-12 gene transfer alone $(p<0.0301)$. Six of the 8 mice treated with Ad.IL-12 plus Ad.CD/5-FC, but only 4 of the 8 mice treated with Ad.IL-12 plus Ad.GFP/5-FC, became tumorfree and survived at 88 days. The mean survival times were $80.5 \pm 20.8$ days for the Ad.IL- $12+$ Ad.CD/5-FC group and $67.3 \pm 28.3$ days for the Ad.IL-12 + Ad.GFP/5-FC group; the difference is statistically significant $(p<0.0368)$.

\section{Conclusion}

Among various cancer gene therapies, immunogene therapy is a promising but challenging modality. Recent clinical trials using Ad.IL-12 have shown that intratumoral IL12 gene transfer is a feasible and well-tolerated procedure but exerts only mild antitumor effects [24]. An increased Ad.IL-12 dose may increase the antitumor efficacy but might entail a systemic, toxic effect that would limit the use of Ad.IL-12 alone. In this study we have attempted to improve the antitumor efficacy in Renca tumor-bearing mice by using adenoviral vectors to transfer the IL-12 gene in combination with cytosine deaminase, followed by 5-FC treatment. The results show a marked inhibition of tumor growth and significant prolongation of survival time, suggesting that IL-12 plus CD gene transfer followed by 5-FC treatment may be an alternative modality for the human cancer treatment.

\section{Abbreviations}

Ad: adenovirus; IL-12: interleukin-12; CD: cytosine deaminase; 5-FC: 5-fluorocytosine; DMEM: Dulbecco's Modified Eagle's Medium.

\section{Competing interests}

The author(s) declare that they have no competing interests.

\section{Authors' contributions}

Cho W-K and Yoo J constructed the adenoviral vectors and analyzed the functionality of the expressed gene products. Hwang K-S, Yun H-J, and Kim S performed the tumor growth studies in the animal model, and the immunological assays with murine splenocytes. Im DS drafted the manuscript.

\section{Acknowledgements}

We are grateful to Yong J. Lee at University of Pittsburgh School of Medicine, Pittsburgh, PA, USA, for providing us with cytosine deaminase. This study was supported by a grant from the KRIBB Initiative Program, a grant from the 2IC FrontierFunctional Genome Project from the Ministry of Science and Technology, Republic of Korea, and a grant from Samyang Genex Biotech Research Institute.

\section{References}

I. Chen SH, Chen XH, Wang Y, Kosai K, Finegold MJ, Rich SS, Woo SL: Combination gene therapy for liver metastasis of colon carcinoma in vivo. Proc Natl Acad Sci U S A 1995, 92:2577-258I.

2. Chen SH, Kosai K, Xu B, Pham-Nguyen K, Contant C, Finegold MJ, Woo SL: Combination suicide and cytokine gene therapy for hepatic metastases of colon carcinoma: sustained antitumor immunity prolongs animal survival. Cancer Res 1996, 56:3758-3762.

3. Felzmann T, Ramsey WJ, Blaese RM: Characterization of the antitumor immune response generated by treatment of murine tumors with recombinant adenoviruses expressing HSVtk, IL-2, IL-6 or B7-I. Gene Ther 1997, 4: I 322-I329.

4. Cao X, Ju DW, Tao Q, Wang J, Wan T, Wang BM, Zhang W, Hamada $\mathrm{H}$ : Adenovirus-mediated GM-CSF gene and cytosine deaminase gene transfer followed by 5 -fluorocytosine administration elicit more potent antitumor response in tumorbearing mice. Gene Ther 1998, 5: I I30-I I36.

5. Ju DW, Wang BM, Cao X: Adenovirus-mediated combined suicide gene and interleukin-2 gene therapy for the treatment of established tumor and induction of antitumor immunity. J Cancer Res Clin Oncol 1998, I 24:683-689.

6. Drozdzik M, Qian C, Xie X, Peng D, Bilbao R, Mazzolini G, Prieto J: Combined gene therapy with suicide gene and interleukin- I 2 is more efficient than therapy with one gene alone in a murine model of hepatocellular carcinoma. J Hepatol 2000, 32:279-286

7. Toda M, Martuza RL, Rabkin SD: Combination suicide/cytokine gene therapy as adjuvants to a defective herpes simplex virus-based cancer vaccine. Gene Ther 200I, 8:332-339.

8. Nakamori M, Iwahashi M, Ueda K, Tsunoda T, Terasawa H, Hamada $H$, Yamaue $H$ : Dose of adenoviral vectors expressing interleukin-2 plays an important role in combined gene therapy with cytosine deaminase/5-fluorocytosine: preclinical consideration. Jpn J Cancer Res 2002, 93:706-7I5.

9. Goto T, Nishi T, Kobayashi O, Tamura T, Dev SB, Takeshima H, Kochi M, Kuratsu J, Sakata T, Ushio Y: Combination electro-gene therapy using herpes virus thymidine kinase and interleukin12 expression plasmids is highly efficient against murine carcinomas in vivo. Mol Ther 2004, 10:929-37.

10. Kobayashi M, Fitz L, Ryan M, Hewick RM, Clark SC, Chan S, Loudon $R$, Sherman F, Perussia $B$, Trinchieri $G$ : Identification and purification of natural killer cell stimulatory factor (NKSF), a cytokine with multiple biologic effects on human lymphocytes. J Exp Med 1989, I 70:827-845.

I I. Wolf SF, Temple PA, Kobayashi M, Young D, Dicig M, Lowe L, Dzialo $R$, Fitz L, Ferenz C, Hewick RM: Cloning of cDNA for natural killer cell stimulatory factor, a heterodimeric cytokine with multiple biologic effects on $\mathbf{T}$ and natural killer cells. J Immunol 1991, | 46:3074-3081.

12. Wolf SF, Sieburth D, Sypek J: Interleukin I2: A key modulator of immune function. Stem Cells 1994, I 2: I54- I68.

13. Brunda MJ: Role of ILI 2 as an anti-tumour agent: current status and future directions. Res Immunol 1995, | 46:622-628.

14. Ma X, Trinchieri G: Regulation of interleukin-I 2 production in antigen-presenting cells. Adv Immunol 200I, 79:55-92.

15. Atkins MB, Robertson MJ, Gordon M, Lotze MT, DeCoste M, DuBois JS, Ritz J, Sandler AB, Edington HD, Garzone PD, Mier JW, Canning CM, Battiato L, Tahara H, Sherman ML: Phase I evaluation of intravenous recombinant human interleukin 12 in patients with advanced malignancies. Clin Cancer Res 1997, 3:409-4I7.

16. Robertson MJ, Cameron C, Atkins MB, Gordon MS, Lotze MT, Sherman ML, Ritz J: Immunological effects of interleukin 12 administered by bolus intravenous injection to patients with cancer. Clin Cancer Res 1999, 5:9-16.

17. Leonard JP, Sherman ML, Fisher GL, Buchanan LJ, Larsen G, Atkins MB, Sosman JA, Dutcher JP, Vogelzang NJ, Ryan JL: Effects of singledose interleukin- 12 exposure on interleukin- 12 -associated toxicity and interferon-gamma production. Blood 1997, 90:254 I-2548.

18. Golab J, Zagozdzon R: Antitumor effects of interleukin-12 in pre-clinical and early clinical studies. Int J Mol Med 1999, 3:537-544.

19. van Herpen CM, Looman M, Zonneveld M, Scharenborg N, de Wilde PC, van de Locht L, Merkx MA, Adema GJ, de Mulder PH: Intratumoral administration of recombinant human interleukin 12 
in head and neck squamous cell carcinoma patients elicits a T-helper I profile in the locoregional lymph nodes. Clin Cancer Res 2004, 10:2626-2635.

20. Burke F: Cytokines (IFNs, TNF-alpha, IL-2 and IL-I 2) and animal models of cancer. Cytokines Cell Mol Ther 1999, 5:5 I-6I.

21. Shurin MR, Esche C, Peron JM, Lotze MT: Antitumor activities of IL-I 2 and mechanisms of action. Chem Immunol 1997 68: $153-174$.

22. Barajas M, Mazzolini G, Genove G, Bilbao R, Narvaiza I, Schmitz V Sangro B, Melero I, Qian C, Prieto J: Gene therapy of orthotopic hepatocellular carcinoma in rats using adenovirus coding for interleukin I2. Hepatology 200I, 33:52-6I.

23. Chada S, Ramesh R, Mhashilkar AM: Cytokine- and chemokinebased gene therapy for cancer. Curr Opin Mol Ther 2003 5:463-474.

24. Sangro B, Mazzolini G, Ruiz J, Herraiz M, Quiroga J, Herrero I, Benito A, Larrache J, Pueyo J, Subtil JC, Olague C, Sola J, Sadaba B, Lacasa C Melero I, Qian C, Prieto J: Phase I trial of intratumoral injection of an adenovirus encoding interleukin- 12 for advanced digestive tumors. J Clin Oncol 2004, 22: I 389-1397.

25. Beltinger C, Uckert W, Debatin KM: Suicide gene therapy for pediatric tumors. J Mol Med 200I, 78:598-6I2.

26. Yazawa K, Fisher WE, Brunicardi FC: Current progress in suicide gene therapy for cancer. World J Surg 2002, 26:783-789.

27. Moolten FL: Tumor chemosensitivity conferred by inserted herpes thymidine kinase genes: paradigm for a prospective cancer control strategy. Cancer Res 1986, 46:5276-528I.

28. Austin EA, Huber BE: A first step in the development of gene therapy for colorectal carcinoma: cloning, sequencing, and expression of Escherichia coli cytosine deaminase. Mol Pharmacol 1993, 43:380-387.

29. Kilstrup M, Meng LM, Neuhard J, Nygaard P: Genetic evidence for a repressor of synthesis of cytosine deaminase and purine biosynthesis enzymes in Escherichia coli. J Bacteriol 1989 , | 7 I:2I 24-21 27.

30. Mullen CA, Kilstrup M, Blaese RM: Transfer of the bacterial gene for cytosine deaminase to mammalian cells confers lethal sensitivity to 5-fluorocytosine: a negative selection system. Proc Natl Acad Sci U S A 1992, 89:33-37.

31. Schilsky RL: Biochemical and clinical pharmacology of 5-fluorouracil. Oncology 1998, I2:13-18.

32. Freeman SM, Abboud CN, Whartenby KA, Packman CH, Koeplin DS, Moolten FL, Abraham GN: The "bystander effect": tumor regression when a fraction of the tumor mass is genetically modified. Cancer Res 1993, 53:5274-5283.

33. Huber BE, Austin EA, Richards CA, Davis ST, Good SS: Metabolism of 5-fluorocytosine to 5-fluorouracil in human colorectal tumor cells transfectd with the cytosine deaminase gene: significant antitumor effects when only a small percentage of tumor cells express cytosine deaminase. Proc Natl Acad Sci U S A 1994, $91: 8302-8306$

34. Wygoda MR, Wilson MR, Davis MA, Trosko JE, Rehemtulla A, Lawrence TS: Protection of herpes simplex virus thymidine kinase-transfectd cells from ganciclovir-mediated cytotoxicity by bystander cells: the Good Samaritan effect. Cancer Res 1997, 57:1699-1703.

35. Kievit E, Nyati MK, Ng E, Stegman LD, Parsels J, Ross BD, Rehemtulla A, Lawrence TS: Yeast cytosine deaminase improves radiosensitization and bystander effect by 5 -fluorocytosine of human colorectal cancer xenografts. Cancer Res 2000, 60:6649-6655.

36. Crystal RG, Hirschowitz E, Lieberman M, Daly J, Kazam E, Henschke C, Yankelevitz D, Kemeny N, Silverstein R, Ohwada A, Russi T, Mastrangeli A, Sanders A, Cooke J, Harvey BG: Phase I study of direct administration of a replication deficient adenovirus vector containing the $E$. coli cytosine deaminase gene to metastatic colon carcinoma of the liver in association with the oral administration of the pro-drug 5-fluorocytosine. Hum Gene Ther 1997, 8:985-1001.

37. Pandha HS, Martin LA, Rigg A, Hurst HC, Stamp GW, Sikora K, Lemoine NR: Genetic prodrug activation therapy for breast cancer: A phase I clinical trial of erbB-2-directed suicide gene expression. J Clin Oncol 1999, I7:2180-2189.

38. Nemunaitis J, Cunningham C, Senzer N, Kuhn J, Cramm J, Litz C, Cav agnolo R, Cahill A, Clairmont C, Sznol M: Pilot trial of genetically modified, attenuated Salmonella expressing the E. coli cyto- sine deaminase gene in refractory cancer patients. Cancer Gene Ther 2003, 10:737-744.

39. Izquierdo M, Martin V, de Felipe P, Izquierdo JM, Perez-Higueras A, Cortes ML, Paz JF, Isla A, Blazquez MG: Human malignant brain tumor response to herpes simplex thymidine kinase (HSVtk)/ganciclovir gene therapy. Gene Ther 1996, 3:491-495.

40. Stockhammer G, Brotchi J, Leblanc R, Bernstein M, Schackert G Weber F, Ostertag C, Mulder NH, Mellstedt H, Seiler R, Yonekawa Y, Twerdy K, Kostron H, De Witte O, Lambermont M, Velu T, Laneuville P, Villemure JG, Rutka JT, Warnke P, Laseur M, Mooij JJ, Boethius J, Mariani L, Gianella-Borradori A: Gene therapy for glioblastoma multiform: in vivo tumor transduction with the herpes simplex thymidine kinase gene followed by ganciclovir. J Mol Med 1997, 75:300-304.

4I. Ram Z, Culver KW, Oshiro EM, Viola J], DeVroom HL, Otto E, Long Z, Chiang Y, McGarrity GJ, Muul LM, Katz D, Blaese RM, Oldfield EH: Therapy of malignant brain tumors by intratumoral implantation of retroviral vector-producing cells. Nat Med 1997, 3:|354-|36|

42. Klatzmann D, Cherin P, Bensimon G, Boyer O, Coutellier A, Charlotte F, Boccaccio C, Salzmann JL, Herson S: A phase I/II dose-escalation study of herpes simplex virus type I thymidine kinase "suicide" gene therapy for metastatic melanoma. Study Group on Gene Therapy of Metastatic Melanoma. Hum Gene Ther 1998, 9:2585-2594.

43. Shand N, Weber F, Mariani L, Bernstein M, Gianella-Borradori A Long Z, Sorensen AG, Barbier N: A phase I-2 clinical trial of gene therapy for recurrent glioblastoma multiforme by tumor transduction with the herpes simplex thymidine kinase gene followed by ganciclovir. GLI328 European-Canadian Study Group. Hum Gene Ther 1999, 10:2325-2335.

44. Packer RJ, Raffel C, Villablanca JG, Tonn JC, Burdach SE, Burger K, LaFond D, McComb JG, Cogen PH, Vezina G, Kapcala LP: Treatment of progressive or recurrent pediatric malignant supratentorial brain tumors with herpes simplex virus thymidine kinase gene vector-producer cells followed by intravenous ganciclovir administration. Neurosurg 2000, 92:249-254.

45. Sandmair AM, Loimas S, Puranen P, Immonen A, Kossila M, Puranen $M$, Hurskainen $H$, Tyynela $K$, Turunen $M$, Vanninen $R$, Lehtolainen $P$, Paljarvi L, Johansson R, Vapalahti M, Yla-Herttuala S: Thymidine kinase gene therapy for human malignant glioma, using replication-deficient retroviruses or adenoviruses. Hum Gene Ther 2000, I I:2197-2205.

46. Rainov NG: A phase III clinical evaluation of herpes simplex virus type I thymidine kinase and ganciclovir gene therapy as an adjuvant to surgical resection and radiation in adults with previously untreated glioblastoma multiforme. Human Gene Ther 2000, I I:2389-240 I.

47. Smitt PS, Driesse M, Wolbers J, Kros M, Avezaat C: Treatment of relapsed malignant glioma with an adenoviral vector containing the herpes simplex thymidine kinase gene followed by ganciclovir. Mol Ther 2003, 7:85I-858.

48. Park J-H, Chang $\mathrm{S}-\mathrm{H}$, Lee $\mathrm{K}-\mathrm{M}$, Lee $\mathrm{H}-\mathrm{K}$ : Murine sarcoma cells transfected with interleukin- $I 2$ are rejected in vivo inducing protective and curative immune response against the parental cells. Mol Cells 1995, 5:595-564.

49. Seong YR, Choi S, Lim JS, Lee CH, Lee CK, Im DS: Immunogenicity of the EIE2 proteins of hepatitis $C$ virus expressed by recombinant adenoviruses. Vaccine 200I, I9:2955-2964.

50. Hwang KS, Cho WK, Yoo J, Seong YR, Kim BK, Kim S, Im DS: Adenovirus-mediated interleukin- 18 mutant in vivo gene transfer inhibits tumor growth through the induction of $T$ cell immunity and activation of natural killer cell cytotoxicity. Cancer Gene Ther 2004, I I:397-407.

5I. Cho WK, Seong YR, Lee YH, Kim MJ, Hwang K-S, Yoo J, Choi S, Jung CR, Im DS: Oncolytic effect of adenovirus mutant capable of replicating in hypoxic and normoxic regions of solid tumor. Mol Ther 2004, 1 0:938-949.

52. Bramson J, Hitt M, Gallichan WS, Rosenthal KL, Gauldie J, Graham FL: Construction of a double recombinant adenovirus vector expressing a heterodimeric cytokine: in vitro and in vivo production of biologically active interleukin-12. Hum Gene Ther 1996, 7:333-342.

53. Chen L, Chen D, Block E, O'Donnell M, Kufe DW, Clinton SK: Eradication of murine bladder carcinoma by intratumor injection of a bicistronic adenoviral vector carrying cDNAs for the IL- 
12 heterodimer and its inhibition by the IL- 12 p40 subunit homodimer. J Immunol 1997, I 59:35I-359.

54. Vile RG, Nelson JA, Castleden S, Chong H, Hart IR: Systemic gene therapy of murine melanoma using tissue specific expression of the HSVtk gene involves an immune component. Cancer Res 1994, 54:6228-6234.

55. Consalvo M, Mullen CA, Modesti A, Musiani P, Allione A, Cavallo F, Giovarelli M, Forni G: 5-Fluorocytosine-induced eradication of murine adenocarcinomas engineered to express the cytosine deaminase suicide gene requires host immune competence and leaves an efficient memory. J Immunol 1995, 154:5302-5312.

56. Pavlovic J, Nawrath M, Tu R, Heinicke T, Moelling K: Anti-tumor immunity is involved in the thymidine kinase-mediated killing of tumors induced by activated Ki-ras(GI2V). Gene Ther 1996, 3:635-643.

57. Freeman SM, Ramesh R, Marrogi AJ: Immune system in suicidegene therapy. Lancet 1997, 349:2-3.

\section{Pre-publication history}

The pre-publication history for this paper can be accessed here:

http://www.biomedcentral.com/1471-2407/5/51/prepub

Publish with Biomed Central and every scientist can read your work free of charge

"BioMed Central will be the most significant development for disseminating the results of biomedical research in our lifetime. "

Sir Paul Nurse, Cancer Research UK

Your research papers will be:

- available free of charge to the entire biomedical community

- peer reviewed and published immediately upon acceptance

- cited in PubMed and archived on PubMed Central

- yours - you keep the copyright

Submit your manuscript here:

http://www.biomedcentral.com/info/publishing_adv.asp
BioMedcentral 